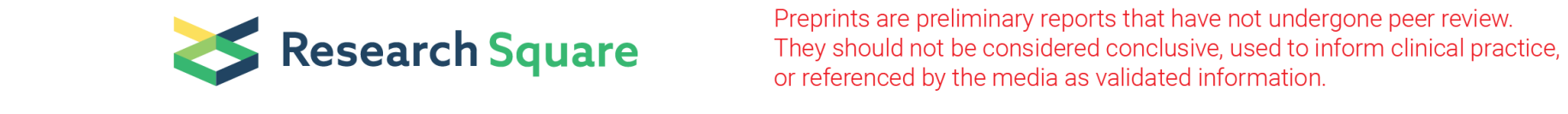

\title{
Multifunctional Rural Transition Along China's Yangtze River Transect: Spatial differentiation and Economic Relevance
}

\author{
Tianhe Jiang \\ Hohai University School of Public Administration \\ Guoqing Shi \\ Hohai University School of Public Administration \\ Yingnan Zhang ( $\nabla$ zhangyn.16b@igsnrr.ac.cn ) \\ Institute of Geographic Sciences and Natural Resources Research Chinese Academy of Sciences
}

\section{Research Article}

Keywords: rural transformation development, living-production-ecology functions, assessing indicator system, rural planning

Posted Date: February 8th, 2021

DOI: https://doi.org/10.21203/rs.3.rs-156838/v1

License: (c) (i) This work is licensed under a Creative Commons Attribution 4.0 International License. Read Full License 


\section{Abstract}

To understand rural sustainability, it is necessary to scrutinize the relationship between rural transition and economic growth. The article uses rural multifunctionality as an analytical lens through which to view the processes of the development of rural occupancy. There is a pressing need to ascertain how to quantify rural multifunctionality and reveal its spatial differentiation, as well as garner and investigate how multifunctional rural transition (MRT) responds to economic growth. This paper employed the concept of Transect to compensate for data deficiencies in a long temporal series and established the indicator system from three different aspects- "living function, production function, and ecological function", to measure MRT along China's Yangtze River Transect. Our analysis showed that living function and production function display an increasing trend from underdeveloped western regions to eastern economically prosperous regions, and represent a high degree surrounding urban agglomerations, while economic growth only leads to a statistically insignificant decreasing trend in ecological function. The MRT resulting from multiple factors is much diverse, complex, sophisticated, therefore, it should be understood within a framework incorporating both endogenous and exogenous factors. According to the results, it is thus important to formulate differentiated managerial countermeasures corresponding to the economic development level rather than the uniform regulations.

\section{Introduction}

Rural, a conception initially flat and uni-dimensional, has been made complex and ambiguous (Wilson, 2001), especially in rural areas of the developed or rapidly urbanized economies (Murdoch, 2000; Woods, 2010). To clearly sketch the plurality of rural areas, "rural multifunctionality" - an integrated theoretical perspective - grows in popularity amid the strands of intellectual explanations to the rural changes. It derives from the research about the function variation of agricultural systems (CEC, 1988), which is of great significance for sustainable rural development (Renting et al., 2009). Still, there remain reflections indicated that, the broader dynamics of rural change were neglected as agriculture production is currently only one of the multiple functions rather than the central of rural (McCarthy, 2005). Therefore, under the influence of hybridized theory (Cloke and Goodwin, 1992), theoretical pluralism (Murdoch, 2000) et al., the thinking of multifunctional agriculture critically evolves into another recognition which treats the multifunctionality as an increasingly important attribute in overall rural occupancy (Holmes, 2012).

Rural multifunctionality performs a non-absolute and neutralized response oscillating between agriculture-centered "productionism" and the "post-productionism" with anti-agriculture philosophy (Wilson, 2001). As it treats agricultural production as a requisite but deems it insufficient to portray the whole picture of rural. This means that there exists rare direct link between rural multifunctionality and traditional agricultural production, and multifunctional rural development might be at the expense of or concert with agriculture production (López-i-Gelats et al., 2015). It is noteworthy that "rural multifunctionality" is distinguished from "multifunctional rural" which is seemingly an ideal post-production pattern and contains some imaginative elements. Rural multifunctionality is prone to be a developing state of rural regions, fully embodies in a more specific and tangible transition concluding with various positions of incomplete changes. This transition is also the process of liberating the concept of rural from its previous close connection to agriculture (Holmes, 2012). Generally, the "multifunctionality" integrally represents the rural "diversity, non-linearity and spatial heterogeneity" (Almstedt et al., 2014), constructing a networked and innovative fabric of rural, yet differs from another definition of "rurality" which assembles overcomplicated and metaphysical elements (Woods, 2010).

The course of history in western rural have witnessed that the multifunctional rural transition (MRT) was inextricably knit with the economic background. At the beginning of post-war economy recovery in the 1950s, the western rural centered on agricultural production for a long time (Wilson, 2001). When finishing the economic capital accumulation, the occurrence of non-farm largescale enterprises was reported in some developed countries, changing the Fordist rural production pattern (the so-called "Fordist transition") (Cloke and Goodwin, 1992). Since the 1970s, cleaner agricultural production through contamination control was enshrined in laws (e.g. U.S.EPA, 2013) and campaign-style rural beautification (Thomas, 2020) were launched in some leading western countries, which endows rural development with ecological protection contents. In the following decades, rural was shaped into a pastoral idyll, triggering the rural gentrification action of "counter-urbanization" (Phillips, 2010). That is, the urban middle class spontaneously moved to the hinterlands, which to some extent, indicated that the function of living consumption gradually became prevalent in rural regions. However, rare existing literature shed light on MRT, and, moreover, how MRT responds to regional economic growth remains unclear. 
Following the path of theoretical development, empirical research emerges from agriculture sector. Relevant studies mainly contributed to the assessment and development of agriculture multifunctionality (Kizos et al., 2011; Wilson, 2008), landscape multifunctionality (Gulickx et al., 2013), land use multifunctionality (Siciliano, 2012), et al. As the theory evolves and enriches with rural variation, a substantial body of research and commentary provided a more complete articulation of the concept of MRT (Holmes, 2010). The transition of agrarian issues including multifunctional livelihood, planting structure (Martin and Lorenzen, 2016), farmland use and rural settlement (Qu et al., 2017) et al. were further investigated to portray the plurality of rural change. Nevertheless, these researches mainly focus on developed economies (Cui et al., 2020), while the similar but delayed functional changes in developing countries were drawn less research attentions. Limited available works (Yang et al., 2019; Yang et al., 2020) have carried out comprehensive analysis towards rural multifunctionality, but mostly remained pragmatical evaluations based on the given administrative units, revealing a distinct paucity of theoretical exploration.

To address this gap, this paper adopts multivariate analysis which is one of the common techniques to deal with indicators, and draws the Transect of Yangtze River as study area where incorporates gradual economic characteristics. These settings are helpful to garner and analyze the spatial pattern of rural multifunctionality and its reciprocity with economic growth, through which the general mechanism of MRT can be further disclosed. The remainder of this paper is organized as follows: Sect. 2 reviews the historical trajectory of MRT in China from the perspective of policy transformation. In Sect. 3, the hypothesis is put forward based on theoretical analysis. Then, this paper proceeds with a description of the study area and methodology. Section 5 elicits the results. Discussions are provided in Sect. 6 . The last part presents and concludes our findings.

\section{Multifunctional Transition In Rural China: A Policy Perspective}

MRT in contemporary China are determined by socio-economic level and national policy. It has experienced a spiral growth course that can be divided into four phases:

\section{Phase I (1949-1977)}

The new founded People's Republic of China once made efforts to promote the transformation from ancient rural society towards the process of industrialization; therefore, the prices of agricultural products were artificially lowered to secure the capital accumulation of heavy industry (Liu et al., 2018; Wang et al., 2014). In light of such implementation of agricultural "price scissors" institution, the unsubstantial agricultural foundation and even the "rural malaise" was shaped at this stage.

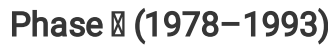

Since the reform and opening-up policy in 1978, the de-collectivization, which aimed to endow private sectors with well-delineated property rights, caused the disillusionment of the Maoist model that nationalized all production resources by establishing cooperatives and unified marketing (Bing et al., 2018). With the help of land adjustment and foreign capital, the liberated individual economy fueled the townships and village-owned enterprises (TVEs) covering various fields (Huang et al., 2020; Wang et al., 2008), such as agriculture, industry, commerce, construction, transportation, and service sector, etc. In the golden age (mid-1980s to mid1990s), the total output value of these rural enterprises exceeded that of agriculture, and the swift annual growth rate of TVE employees amounted to 9\% (Qu et al., 2009). The MRT germinated during this period.

\section{Phase \(1994-2004)}

In 1994, tax sharing reform revamped central-local revenue-sharing arrangements, achieving a recentralization of the fiscal system, but causing the local governments to fail in making ends meet (Rogers, 2014). Making matters worse, the industrialization and urbanization profited from the rural land transaction through legitimated approaches conferred by Land Management Law. Also, increasing competition from both overseas and domestic markets promoted rural enterprises to be restructured or collapsed. The rural area was no longer able to act as an ideal place to hold labor forces (Qu et al., 2009). Hence, millions of farmers migrated to economically prosperous areas. Rural industrialization peaked in 2000 , while this prosperity was gradually overshadowed by the tremendous rural outmigration (Liu et al., 2018), thus delaying the MRT.

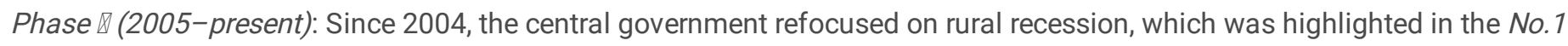
Central Document (Liu et al., 2018). Then, the Eleventh Five-Year Plan claimed a new rural revival strategy - Construction of New 
Socialist Countryside (CNSC). It aimed to renovate rural areas with the guidelines "production is developed, life is high-standard, the environment is clean, and management is democratic" (Rogers, 2014). The contribution of CNSC to rural multifunctionality lies in encouraging the diversification of the rural economy, improving the environment and life quality. In the following years, coordinated urban-rural development has become a major political issue. These central government's documents successively addressed the following: terminating agricultural tax, increasing farmers' incomes, developing modern agriculture, advancing the "Building Beautiful Countryside" scheme (Rogers, 2014), etc. Issues related to prospering rural areas enhanced production and living functions, at the same time, underlined the protection of agro-environment (Cai and Yu, 2018). In 2012, another new strategy named New-type Urbanization was proposed to ameliorate rural degradation and promote rural sustainability (Liu et al., 2018). The guidelines were updated to narrowing the gaps between urban and rural, and realizing urban-rural integrated development. The central government's goals transformed from GDP-centered development to eco-friendly growth, highlighting the integrated development of different industries relying on rural environment and resources (Zhang et al., 2019). In 2017, Rural Vitalization, with the guidelines of "thriving business, pleasant living environment, social etiquette and civility, effective governance and property" was implemented to prevent rural declines and to promote rural transformation development (Long et al., 2019). Such external supports delineated the trajectory of rural development, which gradually accelerated the MRT.

\section{Hypothesis}

The above discussion regarding China's rural transformation development has revealed that relevant policies, which are parallel with sustained economic changes, are highly coupled with MRT. Western experiences suggest that the effect of economic growth is not only influenced by the chronicled background but also determined by the regional discrepancies (Râmniceanu and Ackrill, 2007). Therefore, rural multifunctionality needs to be considered from both historical and geographical perspectives.

Regional economic development stimulates the population aggregation and attracts more people to get employed in urban regions through considerable revenue, reliable public services, high transportation accessibility, etc. In turn, the improvement of life quality corresponding to the regional development stage would give rise to various demands in terms of diet changes, tourism, leisure, exquisite environment, as well as the yearning for a peaceful life. Generally speaking, in the underdeveloped areas, subsistence production is emphasized, while the demand for enjoyment and self-development in the developed areas is higher, which follows Maslow's hierarchy of needs (Sirgy, 1986). Building on this rule, an inference can be drawn that economic growth is associated with urban residents' demands for rural areas, further driving the MRT.

Regional development is highly correlated with the regional location advantage, which affects the industry distribution and development direction. High-efficiency enterprises tend to be arranged in coastal regions of China, which attracts more investments and has high mobility. Following the rule of industry transfer, industries with high pollution or low value-added would be moved to inland regions. Therefore, there exists a stratified development stage from coastal to inland regions (Martin and Ottaviano, 1999). As discussed above, the driving effect of regional economic growth on rural transformation is expected to be highly heterogeneous.

Owing to the increasing land demand, economic development inevitably compresses the space for environmental value. Urban sprawl has resulted in that tremendous ecological land was encroached. Inverted-U-shaped relationships could be observed among economic growth and arable land occupation (Song, 2014), deforestation (Zhang, 2000), wetland destruction, nature reserves overexploitation (Ke et al., 2011), etc. Specifically, the first halves of these curves commonly exhibit strong antagonism between economic development and environmental protection. After reaching the turning point, enhanced environmental awareness and advanced technology might be helpful for environmental conservation (Ricci, 2007). This implies that the general development mode of "treatment after pollution" in China is indeed subject to regional disparities. Nonetheless, predatory development is still a major threat to rural sustainability. Based on the above arguments, hypothesis 1 is proposed as follows:

\section{$\mathrm{H}_{1}$ : Rural multifunctionality would be strengthened with regional economic growth.}

Rural multifunctionality is characterized by the endemic, intense conflicts among multiple values, most commonly occurring in perimetropolitan zones (Holmes, 2012). It implies that the urban area should be taken into account when understanding the rural multifunctionality. One reason is that urban area serves as the role of node and hinge and influences the surrounding rural area (Marshall, 1989; Zhang et al., 2019). This kind of impact can be viewed as a gravitational interaction, which changes with the size and distance of the urban and rural area. Another explanation is that rural areas provide goods and services for urban residents (Gu 
and Pang, 2008). To avoid traffic congestion and environmental pollution, a growing number of large energy-consuming industries move to rural areas, which endows the rural area with the industry sectors. Meanwhile, a vast amount of labor force migrates as the industrial transferring and relocates around the industrial park in the suburb, stimulating the emergence of buildings and other infrastructures. Additionally, the urbanization and industrialization result in diet change and the emphasis on food quality. Among them, the demand for more nutritious food promotes the development of modern agriculture, while the need for daily leisure and short-distance travel accelerates the development of the tertiary industry, such as rural homestay. In contrast to urban, rural is a representation of healthy, relaxing, and recreational paradise (Woods, 2010). Accordingly, we hypothesize that,

$\mathrm{H}_{2}$ : The near-urban rural areas display a higher multifunctionality level than those of remote wildernesses.

\section{Method}

\subsection{Study area}

The east-central-west gap is one of the most typical regional differences in China: the east leads in economic development, the central comes second, and the west is in the last place. Yet the highly unbalanced East-West economic development differences are intertwined with the unmatched South-North differences, which undoubtedly disturbs the correlation analysis. Considering this, the Transect of Yangtze River (TYR) is chosen to investigate the links between economic growth and rural multifunctionality, which can also compensate for data deficiencies in a long temporal series.

As depicted in Fig. 2, the TYR continuum covers 343 counties, where is inhabited by more than $1 / 3$ of the Chinese population. Its total length is about $3600 \mathrm{~km}$ starting from Tibet, and ends in Shanghai, passing through Qinghai, Yunnan, Sichuan, Chongqing, Hunan, Hubei, Jiangxi, Anhui and Jiangsu, and covering the eastern, central and western regions. The TYR has been proven to be a useful tool to reveal regional differences in physical, environmental, social, and economic aspects (Long et al., 2007). As the core region of the Yangtze River Economic Zone defined in the $13^{\text {th }}$ Five Year Plan (The State Council of China, 2016), the TYR is more meaningful for rural renaissance and new-type urbanization.

\subsection{Index system and data source}

Previous studies identified inter-related aspects and indicators about MRT, such as agricultural production, food regimes, and environmental impacts, etc., which are adopted into the conceptual model of "production-consumption-protection" (Holmes, 2012). Yet rural modes of occupancy in the west have limited relevance to China's rural areas, as the dissonance in the social system, economic development stage, land management mode, etc. Building on the review of relevant literature in western countries, we constructed a framework from the dimensions of "living-production-ecology" by considering the characteristics of China's rural areas (Yin et al, 2017), which can be encapsulated as three dimensions (Table 1).

Living function mainly refers to the capability of providing living and leisure space for human beings, as well as guaranteeing material life and spiritual life. The former is embodied in material goods, such as residents' living space security, income, and consumption level, while the latter is reflected in the supply of corresponding supporting facilities and services in the aspects of culture, education, etc. Accordingly, the relevant indicators (LFI) are selected. Then, the production function index (PFI) takes the industrial structure as an essential dimension, which includes direct and indirect production activities. The direct one mainly relies on farmland to obtain material products such as grain crops, cash crops, and livestock products, while the indirect one depends on land construction for achieving goods and service products such as the second and third industries. Finally, the ecological function is the natural surfaces of land use, which plays a role in maintaining ecosystem stability and the capability of self-maintenance. Normalized difference vegetation index (NDVI), topological slope, and the value of ecosystem services are chosen for measuring ecological function.

The data is derived from the "China County Statistical Yearbook (2015)", and the yearbooks of those 11 provinces, as well as the annual statistics from the governmental reports. Other data on roads, terrain, and vegetation coverage, et al. were collected from Data Center for Resources and Environmental Sciences, Chinese Academy of Sciences (CAS, 2020). The spatial distribution of each index is shown in Fig. 3. 


\subsection{Weights calculation and quantifying rural multifunctionality}

Weights determination is a pivotal process when assessing each sub-functions. Although there exist several different methods that have been widely used to set the weights, error, or deviation sometimes occurred. To obtain more accurate results, three methods consisting of the Analytic Hierarchy Process (AHP), Delphi method, and Entropy method are used to compute the weights (Fox, 2017).

A multi-factor comprehensive evaluation was employed to calculate each subfunction and the comprehensive index of rural multifunctionality. The formula is as follows:

$$
\mathrm{RMI}=\sum_{i} I_{i} * W_{i}
$$

where $R M I$ is the rural multifunctionality index, $l_{i}$ represents indicator $i, W_{i}$ indicates the weight of indicator $i$. The standardized indicator values range from 0 to 1 , and the calculated indexes were finally standardized by using the max-min method.

\subsection{Exploratory spatial data analysis (ESDA)}

ESDA is a descriptive and visual-spatial distribution technique to identify and distinguish geographic data features. On this basis, outliers are then observable for the follow-up spatial associations' discovery and clustering, or spatial hot spot patterns. The indicators of Global Moran's I, Local Moran's I are used in this paper for spatial agglomeration characteristics of rural multifunctionality. The former is a commonly used metric, essentially a standardized spatial covariance, to evaluate whether there is a significant spatial autocorrelation from the overall level. The latter is used to identify and analyze the local spatial differentiation pattern. They were accomplished by using the following expressions:

$$
\begin{gathered}
I=\frac{N \sum_{i} \sum_{j} w_{i j}\left(x_{i}-\bar{x}\right)\left(x_{j}-\bar{x}\right)}{\sum_{i} \sum_{j} w_{i j} \sum_{i}\left(x_{i}-\bar{x}\right)^{2}} \\
I_{i}=\frac{\left(x_{i}-\bar{x}\right)}{s_{x}^{2}} \sum_{j}\left[w_{i j}\left(x_{i}-\bar{x}\right)\right]
\end{gathered}
$$

where, I and $I_{i}$ correspond to Moran's I and Local Moran's / respectively; $N$ depicts the unit umber of researched counties; $W_{i j}$ is the spatial weight matrix; $X_{i}$ and $X_{j}$ denote the $R M I$ of county $i$ and $j ;$-is the average value of $R M ; \mathrm{S}_{\mathrm{x}}{ }^{2}$ means the variance.

Table 1 Index system for assessing rural multifunctionality 


\begin{tabular}{|c|c|c|c|c|c|c|c|c|}
\hline Subfunction & Dimensions & Index & Description & References & AHP & Delphi & Entropy & $\begin{array}{l}\text { Arithmetic } \\
\text { mean }\end{array}$ \\
\hline \multirow[t]{5}{*}{$\begin{array}{l}\text { Living } \\
\text { function }\end{array}$} & $\begin{array}{l}\text { Population } \\
\text { Carrying }\end{array}$ & $\begin{array}{l}\text { Rural } \\
\text { population } \\
\text { density }\end{array}$ & $\begin{array}{l}\text { The number of } \\
\text { rural population } \\
\text { /(Total area of } \\
\text { the } \\
\text { administrative } \\
\text { zone - the area } \\
\text { of urban built-up } \\
\text { region) }\end{array}$ & $\begin{array}{l}\text { Yang et al., } \\
2019\end{array}$ & 0.36 & 0.27 & 0.32 & 0.32 \\
\hline & Income level & $\begin{array}{l}\text { Disposable } \\
\text { income }\end{array}$ & $\begin{array}{l}\text { The per capita } \\
\text { disposable } \\
\text { income of rural } \\
\text { residents }\end{array}$ & $\begin{array}{l}\text { Siciliano, } \\
2012\end{array}$ & 0.36 & 0.13 & 0.23 & 0.24 \\
\hline & Health care & $\begin{array}{l}\text { The number of } \\
\text { medical beds }\end{array}$ & $\begin{array}{l}\text { The number of } \\
\text { medical beds / } \\
\text { total population }\end{array}$ & $\begin{array}{l}\text { You et al., } \\
2020\end{array}$ & 0.12 & 0.11 & 0.12 & 0.11 \\
\hline & $\begin{array}{l}\text { Transportation } \\
\text { accessibility }\end{array}$ & Road density & $\begin{array}{l}\mathrm{D}_{i} \text { is the road } \\
\text { nets density of } \\
\text { grid } i ; w_{i} \text { is the } \\
\text { weight of road } \\
\text { type } i, R_{i} \text { is the } \\
\text { density of road } \\
\text { type } i \text { within the } \\
\text { grid } i \text {. The } \\
\text { weights of the } \\
\text { expressway, } \\
\text { national } \\
\text { highway, } \\
\text { provincial-level } \\
\text { highway, } \\
\text { railway, and } \\
\text { county-level } \\
\text { roads were set } \\
\text { as } 0.25,0.20, \\
0.15,0.35 \text {, and } \\
0.05, \\
\text { respectively. }\end{array}$ & $\begin{array}{l}\text { Yang et al., } \\
2019\end{array}$ & 0.11 & 0.28 & 0.18 & 0.19 \\
\hline & Social security & $\begin{array}{l}\text { The number of } \\
\text { beds in social } \\
\text { welfare } \\
\text { institutions }\end{array}$ & $\begin{array}{l}\text { The number of } \\
\text { welfare } \\
\text { adoption beds / } \\
\text { The number of } \\
\text { the total } \\
\text { population }\end{array}$ & $\begin{array}{l}\text { Yang et al., } \\
2019\end{array}$ & 0.07 & 0.21 & 0.15 & 0.14 \\
\hline \multirow[t]{6}{*}{$\begin{array}{l}\text { Production } \\
\text { function }\end{array}$} & $\begin{array}{l}\text { Overall } \\
\text { productivity }\end{array}$ & $\begin{array}{l}\text { Regional } \\
\text { public } \\
\text { financial } \\
\text { revenue } \\
\text { (RPFR) }\end{array}$ & $\begin{array}{l}\text { Regional total } \\
\text { public financial } \\
\text { revenue / The } \\
\text { number of the } \\
\text { total population }\end{array}$ & $\begin{array}{l}\text { You et al., } \\
2020\end{array}$ & 0.32 & 0.17 & 0.21 & 0.23 \\
\hline & & $\begin{array}{l}\text { Fixed asset } \\
\text { investment } \\
\text { (FAl) }\end{array}$ & $\begin{array}{l}\text { Fixed asset } \\
\text { investment/total } \\
\text { population }\end{array}$ & $\begin{array}{l}\text { Râmniceanu } \\
\text { and Ackrill, } \\
2007\end{array}$ & 0.13 & 0.15 & 0.18 & 0.15 \\
\hline & $\begin{array}{l}\text { Agricultural } \\
\text { productivity }\end{array}$ & $\begin{array}{l}\text { Added-value } \\
\text { of agriculture } \\
\text { per capita }\end{array}$ & $\begin{array}{l}\text { Total added } \\
\text { value in } \\
\text { agriculture/ The } \\
\text { number of the } \\
\text { total population }\end{array}$ & $\begin{array}{l}\text { Zhang et al., } \\
2019\end{array}$ & 0.13 & 0.11 & 0.16 & 0.14 \\
\hline & & Grain yield & $\begin{array}{l}\text { Grain yield The } \\
\text { number of the } \\
\text { total population }\end{array}$ & $\begin{array}{l}\text { Yang et al., } \\
2020\end{array}$ & 0.06 & 0.10 & 0.13 & 0.10 \\
\hline & & $\begin{array}{l}\text { Farmland } \\
\text { mechanization } \\
\text { level }\end{array}$ & $\begin{array}{l}\text { Total } \\
\text { agricultural } \\
\text { machinery }\end{array}$ & Floor, 2004 & 0.03 & 0.16 & 0.15 & 0.11 \\
\hline & & & Page $7 / 21$ & & & & & \\
\hline
\end{tabular}




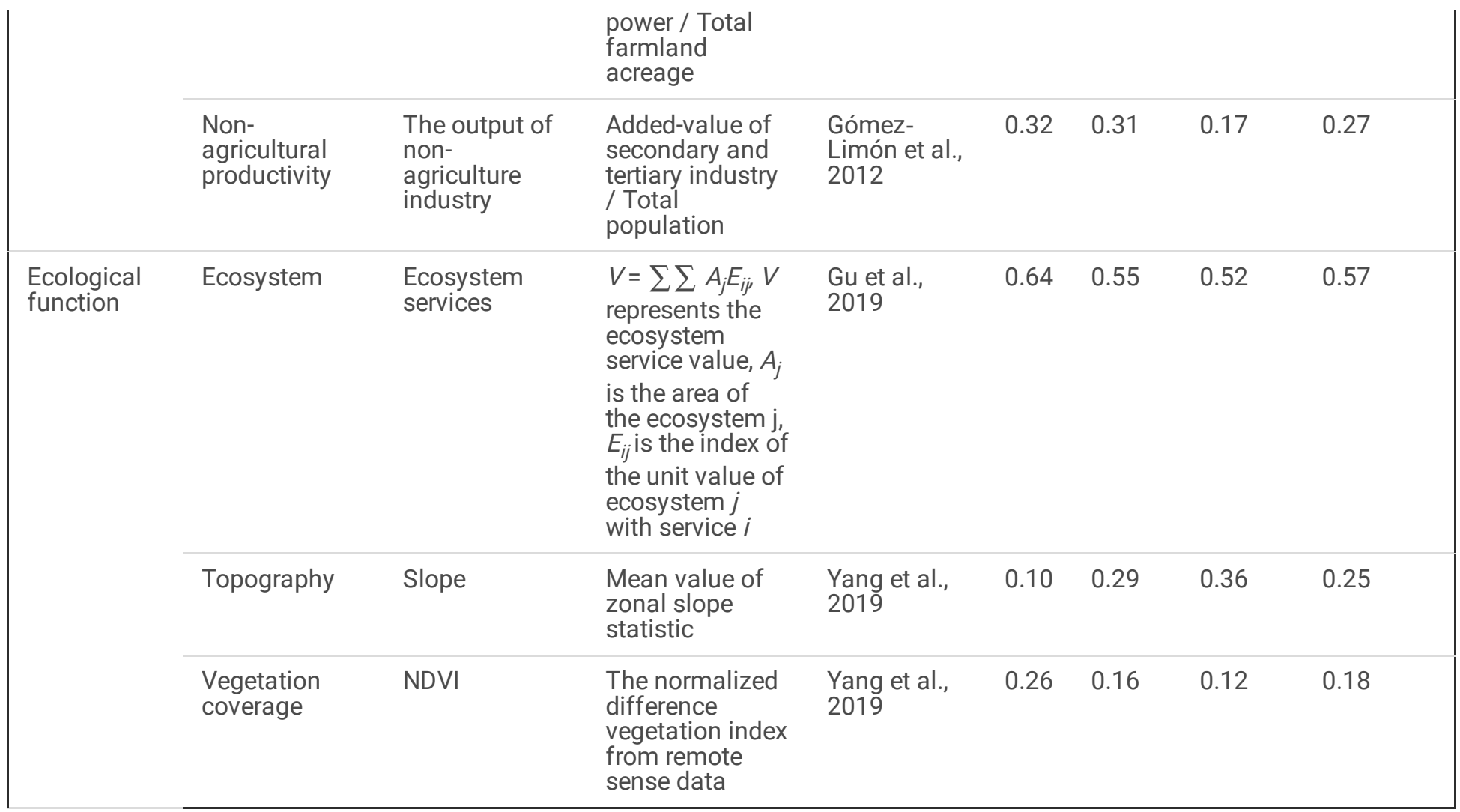

\section{Results}

\subsection{Spatial characteristics of rural multifunctionality}

As diagrammatically represented in Fig. 4a, the high-value areas of LFI are chiefly concentrated in the middle and lower reaches of the Yangtze River, especially the Yangtze River Delta. And the Chengdu-Chongqing Economic Circle also presents a relatively high living function. This phenomenon roots in the location advantage, which creates more opportunities and provides more resources endowments for industry development, naturally attracting more people to get employed. These highly urbanized regions have a strong capacity to offer local residents desirable medical care, transportation accessibility, and social security, presenting consistency highly with that in Fig. 3. The spatial distribution of the high-value area of PFI is generally similar to that in those areas with the prominent living function, but Anhui and Hubei segments are out of the rule. It is mainly attributed to the fact that these regions are located in the middle and lower reaches of the Yangtze River Plain, with a dense population, high ratio of agricultural sector, but underdevelopment of secondary and tertiary industries. Besides, the areas with high EFI are concentrated in the hinterlands of the urban agglomerations. The less human activities and the higher vegetation coverage there provide better ecological services. Nevertheless, these hinterland areas located in mountainous areas with steep terrain are unconducive to infrastructure construction, industrial agglomeration, and urban development, leading to the growing pains of living and production functions. It is worth noting that the headwater area of the Yangtze River is located in the Tibetan Plateau with an average elevation exceeding 4,000 meters, where is sparse populated, poor vegetation covered. Thus, the rural functions there in all aspects are at the lowest.

The zone with high RMFI is mostly distributed in the Yangtze River Delta, Yichang-Jingzhou City Circle, and units surrounding Kunming City. The highest economic and social function in the Yangtze River Delta raises its overall score, while the areas around Yichang-Jingzhou and Kunming weigh the higher eco-function and medium-high living and production function indexes to achieve the high gross value.

The Moran's I is 0.5046, indicating a significant agglomeration effect of RMFI. Specifically, HH (High-High units and located in the first quadrant, the counties with high RMFI surrounded by that with high RMFI) is mainly distributed in the Yangtze River Delta and Yichang; the majority of HL counties (High-Low counties and located in the fourth quadrant, the counties with high RMFI surrounded by that with low RMFI) is scattered in the southwest of China; LH (Low-High counties and located in the second 
quadrant, the units with low RMFI surrounded by that with high RMFI) units are in the minimum amount, appearing as two clusters in the middle-lower Yangtze Valley; the LL (Low-Low counties and located in the third quadrant, the cities with low RMFI surrounded by that with low RMFI) units are widely spread in the western Sichuan Province and Qinghai Province (Fig. 5), which almost coincides with the areas with high EFI.

\subsection{The relationship among the sub-functions}

It can be concluded from Fig. 6 that there exists a strong synergy and positive correlation between living function and production function, whereas both living function and economic function showed weak negative correlations with ecological function. It can be easily understood that a prosperous rural economy is always accompanied with a strong capacity of housing dense population and providing sound public service. In some cases, plain regions, where more rural population inhabits, present high living function, while the production function is not quite high as the nonagricultural production activity is stagnant. This can be manifest in the major grain-producing regions in Anhui and Hubei. The hinderland of urban agglomeration, including Yangtze River Delta city clusters, Chengdu-Chongqing metropolitan area undoubtedly demonstrate intense socio-economic activities, but always are encroached by accelerating urban sprawl. Thus, the ecological space will shrink, and this can signify that the tradeoff exists between socio-economic performance and ecological conservation. Conflicts of construction land and ecological land emerged as prominent in eastern regions, which are preferentially developed in terms of both national and regional strategies.

\subsection{Coupling relationship between economic growth and rural multifunctionality}

To establish the interrelations between economic growth and rural multifunctionality, and substantiate our above-mentioned hypothesis, correlation analysis was used (see Fig.7). Results show that LFI, PFL, and RMFI demonstrate significant positive relations with PCGDP, and the $\mathrm{R}^{2}$ exceeds 0.5 , which signifies $L F I, P F L$, and RMFI gradually increase as the regional economy advances. While economic growth only leads to a statistically insignificant decreasing trend in ecological function. The possible explanation of this phenomenon is that intense contradiction has yet to appear in underdeveloped regions, and the socio-economic development level is relatively low. In economically developed areas, land use is highly contested with limited space that can be exploited. Thus, the relations between socio-economic function and ecological function, to some extent, are determined by regional ecological carrying capacity.

Fig. 8 depicts the spatial tendency of different indexes along the YRT, and the evolution trend is in line with the results in Fig.7, proving the assumption from the spatial perspective. Generally, the LFI, PFI, and RMFI experience wavelike increases from the upper reach to lower reach, peaking at the surrounding areas of urban agglomeration and bottoming at remote wildness. As for LFI, it first increases, reaching a peak around Kunming, and then experiences a slight decrease until Chongqing, and finally proliferates. Concerning PFI, there is a slight increase in Qinghai and Chongqing, after which it goes up dramatically. Differently, EFI presents drastic fluctuations over the whole transect but generally shows a decreasing trend. RMFI remains stable at approximately 0.35 between Qinghai and Guiyang, and then roughly displayed a considerable growth.

\section{Discussion}

\subsection{Insights into the spatial heterogeneity of rural multifunctionality}

The unprecedented process of urbanization with a remarkable urban population boom results in an increasing demand for rural goods and services, driving the multifunctional transition in the suburbs. Our study provides evidence of multifunctional rural development in urban suburbs based on the quantitative evaluation, which is consistent with the findings of Gu et al.'s (2019). This work reveals the "urban-driving" effect of MRT at large scale covering different economic development stages, rather than focusing on a specific urban back-land with limited areas. The increasing trend of living function and production function identified along the TYR also validates the hypothetic associations. It has been recognized that MRT mainly results from external powers, including industry development, regional development policy, foreign investment, etc. There is no doubt that the impact caused by local characteristics cannot be ignored. Thus, the determinants can be encapsulated as endogenous and exogenous factors. The former

Page 9/21 
incorporates the forces that add fuel to rural development momentum and stimulate the external demand of rural goods and services. Urbanization and industrialization are the general schematics of external powers from urban areas. This echoes Lewis' dual development theory, which underlines that the main role of rural economy is to produce products for urban consumption (Lewis 1954; Qin et al. 2020). The latter contains resources endowments, landforms, climatic conditions, infrastructure construction, as well as the location conditions. Following the neoclassical growth theory, resources endowment and infrastructure have been shown significant factors, and have the most explanatory power for rural development (Aggarwal and Shilpa, 2018). It can be easily proved in western regions with fragile ecological conditions, socio-economic activities are not only greatly constrained by highland climate, steep terrain, low traffic accessibility, etc., but also limited by low urbanization level, sparse population, and deficient investment. Therefore, rural multifunctionality is a combined result of multiple factors and should be understood within an intricate network comprising both endogenous and exogenous powers. The spatial heterogeneity of rural multifunctionality revealed by this paper is in sync with the basic organization of a land use system that the traditional agricultural location theory depicts (Fig. 9). Production cost (including labor input), transportation cost and land rent play crucial role in the land use pattern Thünen outlined (O’Kelly and Bryan, 1996). The technic progress in transportation and the increasing multiple demands of urban and rural residents have changed the determinants of industry distribution, especially in the suburb regions. In line with the traditional location theory, the labor and capital intensive planting industry occupies the outskirts of the city, which targets at providing food-oriented products, such as vegetables, fruits, etc. Current improved transportation conditions enables the location selection of cash crops more flexible. The escalating demand of leisure and recreation creates more opportunities for the suburb regions to transform the traditional planting or breeding industry into a combined industry morphology integrating the first, secondary and tertiary industry. The land use patter is accordingly reorganized and the intensive agricultural may be arranged further than ever before.

\subsection{Implications for multifunctional rural planning}

The results revealed the differentiation of the three dimensions of rural occupancy and identified the hotspots of each dimension, which supported the statement of Etxano et al. (2018) that it is not an easy task to satisfy numerous demands within one specific region. This denotes that the appropriate spatial arrangement of functional topology is necessary according to the location and economic development level. The results show clear differences between areas with different trajectories or rural traits and help identify the principal function of a different region. Therefore, counties located in the outskirts of megacities are supposed to strengthen the living and production function, meanwhile, emphasize the protection of ecological space. Strict restriction of farmland occupation should be enforced. Relying on a favorable environment, unique countryside landscape, and the huge market from urban residents, rural tourism might be a better choice for achieving rural sustainability. It has been found that there exists tremendous low-efficiency use of industrial land in the suburbs of Shanghai (Gu et al., 2018). Countermeasures should be taken to reduce inefficient industrial land use to improve the rural ecological environment. Concerning remote underdeveloped counties, promoting agricultural modernization and reinforcing ecological conservation should be underlined, as population outflow is an inevitable trend against the context of accelerated urbanization. Furthermore, regional sustainability requires the collaboration of different areas, which means some counties take living and production as their main responsibility, and other regions need to take full use of their natural conditions to highlight the ecological value, thus realizing regional multifunctional development.

In China's current rural planning, de-agriculturalization has been a pervasive ideological trend, which attempts to separate rural areas into construction land and agricultural production land, and seldom considers the impacts of agricultural land on rural development. In most cases, agricultural land is regarded as ecological matrix, however, its social and cultural functions are ignored. This implies that an understanding of rural development land use as a multifunctional practice is necessary, which is connected with a call for 'integration' and 'diversification' (Mölders, 2014).

\subsection{Limitations and outlooks for future research}

Multi-factor Comprehensive Appraisal Method was employed in this paper to evaluate rural functions, while several major uncertainties should be highlighted when using this method. First, there are no uniformly prescribed guidelines for selecting the most representative criteria. Secondly, thresholds for the overall indicators are unavailable in existing studies to support setting those for the indicators. Besides, this becomes difficult as they vary with regional conditions and socio-economic development levels. 
Although the transect was proved to be an effective tool for compensating data deficiencies in a long temporal series, the unavailability of data denoting detailed sub-functions restricts indicators setting and fails to represent the multidimensionality, such as the leisure function, landscape function, etc. Besides, the cultural function is difficult to be quantified because it should be analyzed through the methods from behavioral geography or sociology. Therefore, research about the appraisal method, variable setting, and how to delineate cultural functions are needed to be highlighted, thus providing a more comprehensive and holistic understanding of rural multifunctionality.

\section{Conclusion}

Attempting to understand how rural multifunctionality responds to economic growth, we established indicator systems with three dimensions for measuring MRT: living function, production function, and ecological function, and quantitatively examined their links to economic growth, as well as delineated the spatial pattern by employing exploratory spatial data analysis (ESDA). The concept of Transect was applied to compensate for data deficiencies in a long temporal series. Various conclusions were drawn: Living function and production function display an increasing trend from underdeveloped western regions to eastern developed regions and represent a high degree surrounding urban agglomerations, while economic growth only leads to a statistically insignificant decrease trend in ecological function. These findings confirm our hypothesis that rural multifunctionality will undergo specific stages corresponding to a particular economic developmental level, and the "urban-driving" effect plays a significant role in the spatial agglomeration of counties with high rural multifunctionality. Both endogenous and exogenous factors contribute to rural multifunctional transition, which should be understood within a comprehensive framework.

Despite the limitations and uncertainties, our findings not only highlighted the difficulty of quantifying rural multifunctionality, but also provide empirical evidence of the relations between economic growth and MRT. Moreover, the trade-off or mutual relations among the three dimensions of rural occupancy can be used for formulating regional spatial planning. Importantly, managerial countermeasures and policy recommendations concerning rural vitalization and sustainable rural development should be designed by considering the economic development level rather than the uniform regulations.

\section{Declarations}

\section{Ethical Approval}

Not applicable

\section{Consent to Participate}

Not applicable

\section{Consentfor publication}

Not applicable

\section{Authors Contributions}

Tianhe Jiang: Conceptualization, Data collection and curation, Original draft writing, Funding acquisition;

Guoqing Shi: Conceptualization, Supervision

Yingnan Zhang: Conceptualization, Methodology, Visualization, Writing - original draft, Writing - review \& editing

\section{Funding}

Fundamental Research Funds for the Central Universities (No. KYCX20_0506)

\section{Competing Interests}

The authors declare that they have no competing interests 


\section{Availability of data and materials}

The datasets generated during and/or analysed during the current study are available from the corresponding author on reasonable request.

\section{References}

Aggarwal, \& Shilpa, 2018. Do rural roads create pathways out of poverty? Evidence from india. Journal of Development Economics, S0304387818300063.

Almstedt, Å., Brouder, P., Karlsson, S., Lundmark, L, 2014. Beyond Post-Productivism: From Rural Policy Discourse to Rural Diversity. European Countryside, 6(4), 297-306.

Bing, P., Zhijun, L., Bingxuan, Z., Xutang, C., 2018. Idyll or nightmare: what does rurality mean for farmers in a Chinese village undergoing commercialization? Inter-Asia Cultural Studies, 19(2), 234-251.

Cai, Y., Yu L., 2018. Rural Households Participation in and Satisfaction with Compensation Program Targeting Farmland Preservation in China, Journal of Cleaner Production, 205, 1148-1161.

Cloke, P., Goodwin, M., 1992. Conceptualizing Countryside Change: From Post-Fordism to Rural Structured Coherence. Transactions of the Institute of British Geographers, 17, 321-336.

Commission of the European Communities (CEC), 1988. The Future of Rural Society. [WWW Document]. URL. https://ec.europa.eu/commission/presscorner/detail/en/P_88_100. Accessed 13 May 2020.

China County Statistical Yearbook, 2015. China Statistical Publishing House, Beijing.

Cui, Y., Liu, W., Sufyan, U., K., Cai., Y., Zhu, J., Deng, Y., Zhao, M., 2020. Regional differential decomposition and convergence of rural green development efficiency: evidence from China, Environmental Science and Pollution Research. 27:22364-22379.

Etxano, I., Barinaga-Rementeria, I., Garcia, O., 2018. Conflicting Values in Rural Planning: A Multifunctionality Approach through Social Multi-Criteria Evaluation. Sustainability 10, 1431.

Evans, N., Morris, C., Winter, M., 2002. Conceptualizing agriculture: a critique of post-productivism as the new orthodoxy. Progress Human Geography. 26, 313-332.

Floor, B., 2004. Sustaining Agriculture and the Rural Environment: Governance, Policy, and Multifunctionality. Edward Elgar Publishing, Cheltenham.

Fox, W.P., 2017. Mathematical Modeling for Business Analytics. CRC Press. Boca Raton.

Gómez-Limón, J.A., Vera-Toscano, E., Rico-González, M., 2012. Measuring Individual Preferences for Rural Multifunctionality: The Importance of Demographic and Residential Heterogeneity. Journal of Agricultural Economics, 63, 1-24.

Gu, C, Pang, H., 2008. Study on spatial relations of Chinese urban system: Gravity Model Approach. Geographical Research, 27(1), $1-12$.

Gu, X., Liu, J., Dai, B., 2018. Suitability assessment of reducing industrial land in Shanghai metropolitan region. Journal of Nature Resources, 33, 1317-1325. (In Chinese)

Gu, X., Xie, B., Zhang, Z., Guo, H. (David), 2019. Rural multifunction in Shanghai suburbs: Evaluation and spatial characteristics based on villages. Habitat International, 92, 102041.

Gulickx, M.M.C., Verburg, P.H., Stoorvogel, J.J., Kok, K., Veldkamp, A., 2013. Mapping landscape services: a case study in a multifunctional rural landscape in The Netherlands. Ecological Indicator, 24, 273-283. 
Holmes, J., 2012. Cape York Peninsula, Australia: A frontier region undergoing a multifunctional transition with indigenous engagement. Journal of Rural Studies, 28, 252-265.

Holmes, J., 2006. Impulses towards a multifunctional transition in rural Australia: Gaps in the research agenda. Journal of Rural Studies, 22, 142-160.

Huang, Q., Song, W., Song, C., 2020. Consolidating the layout of rural settlements using system dynamics and the multi-agent system. Journal of Cleaner Production 274, 123150.

Ke, C., Zhang, D., Wang, F., Chen, S., Schmullius, C., Boerner, W., Wang, H., 2011. Analyzing coastal wetland change in the Yancheng National Nature Reserve, China. Regional Environmental Change, 11, 161-173.

Kizos, T., Marin-Guirao, J.I., Georgiadi, M.-E., Dimoula, S., Karatsolis, E., Mpartzas, A., Mpelali, A., Papaioannou, S., 2011. Survival strategies of farm households and multifunctional farms in Greece. The Geographical Journal, 177, 335-346.

Lewis, A., 1954. Economic development with unlimited supplies of labour. The Manchester school of economic and social studies, 22(2), 139-191.

Liu, S., Wang, R., Shi, G., 2018. Historical Transformation of China's Agriculture: Productivity Changes and Other Key Features. China \& World Economy, 26, 42-65.

Long, H., Heilig, G.K., Li, X., Zhang, M., 2007. Socio-economic development and land-use change: Analysis of rural housing land transition in the Transect of the Yangtse River, China. Land Use Policy, 24, 141-153.

Long, H., Zhang, Y., Tu, S., 2019. Rural vitalization in China: A perspective of land consolidation. Journal of Geographical Sciences, $29,517-530$.

López-i-Gelats, F., Rivera-Ferre, M.G., Madruga-Andreu, C., Bartolomé Filella, J., 2015. Is multifunctionality the future of mountain pastoralism? Lessons from the management of semi-natural grasslands in the Pyrenees. Spanish Journal of Agricultural Research,https://doi.org/10.5424/sjar/2015134-6960

Marshall, J.U., 1989. The Structure of Urban Systems. University of Toronto Press, Toronto.

Martin, P., I.P. Ottaviano, G., 1999. Growing locations: Industry location in a model of endogenous growth. European Economic Review, 43, 281-302.

Martin, S.M., Lorenzen, K., 2016. Livelihood Diversification in Rural Laos. World Development, 83, 231-243.

McCarthy, J., 2005. Rural geography: multifunctional rural geographies - reactionary or radical? Progress of Human Geography, 29, $773-782$.

Murdoch, J., 2000. Networks-a new paradigm of rural development? Journal of Rural Studies. 16, 407-419.

Murdoch, J., Pratt, A.C., 1993. Rural studies: Modernism, postmodernism and the 'post-rural.' Journal of Rural Studies, 9, 411-427.

Mölders T., 2014. Multifunctional agricultural policies: pathways towards sustainable rural development? International Journal of Sociology of Agriculture \& Food, 21(1): 97-114.

O’Kelly M, Bryan D., 1996. Agricultural location theory: von Thunen's contribution to economic geography. Progress in Human geography, 20(4): 457-475.

Phillips, M., 2010. Counterurbanisation and rural gentrification: an exploration of the terms. Population Space and Place, 16, 539558.

Qin, X., Li, Y., Lu, Z., Pan W., 2020. What makes better village economic development in traditional agricultural areas of China? Evidence from 338 villages. Habitat International, 106: 102286.

Page $13 / 21$ 
Qu, J., Zhou, F., Ying, X., 2009. From Macromanagement to Micromanagement--Reflections on Thirty Years of Reform from the Sociological Perspective. Social Sciences in China, 6: 104-127. URL. http://en.cnki.com.cn/Article_en/CJFDTotal-

ZSHK200906008.html

Qu, Y., Jiang, G., Zhao, Q., Ma, W., Zhang, R., Yang, Y., 2017. Geographic identification, spatial differentiation, and formation mechanism of multifunction of rural settlements: A case study of 804 typical villages in Shandong Province, China. Journal of Cleaner Production, 166, 1202-1215.

Râmniceanu, I., Ackrill, R., 2007. EU rural development policy in the new member states: Promoting multifunctionality? Journal of Rural Studies, 23, 416-429.

Renting, H., Rossing, W.A.H., Groot, J.C.J., Van der Ploeg, J.D., Laurent, C., Perraud, D., Stobbelaar, D.J., Van Ittersum, M.K., 2009. Exploring multifunctional agriculture. A review of conceptual approaches and prospects for an integrative transitional framework. Journal of Environmental Management, 90 (S2): 112-S123.

Ricci, F., 2007. Channels of transmission of environmental policy to economic growth: A survey of the theory. Ecological Economics, 60, 688-699.

Rogers, S., 2014. Betting on the strong: Local government resource allocation in China's poverty counties. Journal of Rural Studies, $36,197-206$.

Chinese Academy of Sciences (CAS), 2015. Data Center for Resources and Environmental Sciences. https:// www.resdc.cn. Accessed 25 Apr 2020.

Sibley, D., Atkinson, D., Jackson, P., 2005. Cultural Geography: A Critical Dictionary of Key Ideas. I.B.Tauris, London.

Siciliano, G., 2012. Urbanization strategies, rural development and land use changes in China: A multiple-level integrated assessment. Land Use Policy, 29, 165-178.

Sirgy, M.J., 1986. A Quality-of-Life Theory Derived from Maslow's Developmental Perspective. The American Journal of Economic and Sociology, 45, 329-342.

Song, W., 2014. Decoupling cultivated land loss by construction occupation from economic growth in Beijing. Habitat International, $43,198-205$.

The State Council, 2016. Outline of the 13th Five-Year Plan for the National Economic and Social Development of the People's Republic of China. Beijing.

Thomas, M., 2020. Local Lives, Parallel Histories: Villagers and Everyday Life in the Divided Germany. Oxford University Press, Oxford.

United States Environment Protection Agency (U.S.EPA), 2013. EPA History: Federal Water Pollution Control Act Amendments of 1972. https://www.epa.gov/history/epa-history-federal-water-pollution-control-act-amendments-1972. Accessed 13 May 2020.

van Dam, F., Heins, S., Elbersen, B.S., 2002. Lay discourses of the rural and stated and revealed preferences for rural living. Some evidence of the existence of a rural idyll in the Netherlands. Journal of Rural Studies, 18, 461-476.

Wang, M., Webber, M., Finlayson, B., Barnett, J., 2008. Rural industries and water pollution in China. Journal of Environmental Management, 86, 648-659.

Wang, P, Liu Q., Yu, Q., 2014. Factors influencing sustainable consumption behaviors: a survey of the rural residents in China. Journal of Cleaner Production 63:152-165.

Wilson, G.A., 2008. From 'weak' to 'strong' multifunctionality: Conceptualising farm-level multifunctional transitional pathways. Journal of Rural Studies, 24, 367-383. 
Wilson, G.A., 2001. From productivism to post-productivism ... and back again? Exploring the (un)changed natural and mental landscapes of European agriculture. Transactions of the Institute of British Geographers, 26, 77-102.

Woods, M., 2010. Rural, Routledge, London.

Yang, R., Luo, X., Chen, Y., 2019. Spatial pattern and influencing factors of rural multifunctionality at county level in China, Progress in Geography, 38 (9), 1316-1328. (In Chinese)

Yang, Y., Bao, W., Liu, Y., 2020. Coupling coordination analysis of rural production-living-ecological space in the Beijing-TianjinHebei region. Ecological Indicators, 117: 106512.

You, H., Zhou, D., Wu, S., Hu X., Bie C., 2020. Social Deprivation and Rural Public Health in China: Exploring the Relationship Using Spatial Regression. Social Indicators Research, 147, 843-864.

Yin, G., Liu, L., Jiang, X., 2017. The sustainable arable land use pattern under the tradeoff of agricultural production, economic development, and ecological protection-an analysis of Dongting Lake basin, China. Environmental Science and Pollution Research. 24:25329-25345.

Zhang, P., Yuan, H., Tian, X., 2019. Sustainable development in China: Trends, patterns, and determinants of the "Five Modernizations" in Chinese cities. Journal of Cleaner Production 214, 685-695.

Zhang, Y., 2000. Deforestation and Forest Transition: Theory and Evidence in China, in: Palo, M., Vanhanen, H. (Eds.), World Forests from Deforestation to Transition? (pp. 41-65) World Forests. Springer Netherlands, Dordrecht.

Zhang, Y., Long, H., Ma, L., Tu, S., Li, Y., Ge, D., 2018. Analysis of rural economic restructuring driven by e-commerce based on the space of flows: The case of Xiaying village in central China. Journal of Rural

Studies,https://doi.org/10.1016/j.jrurstud.2018.12.001.

\section{Figures}

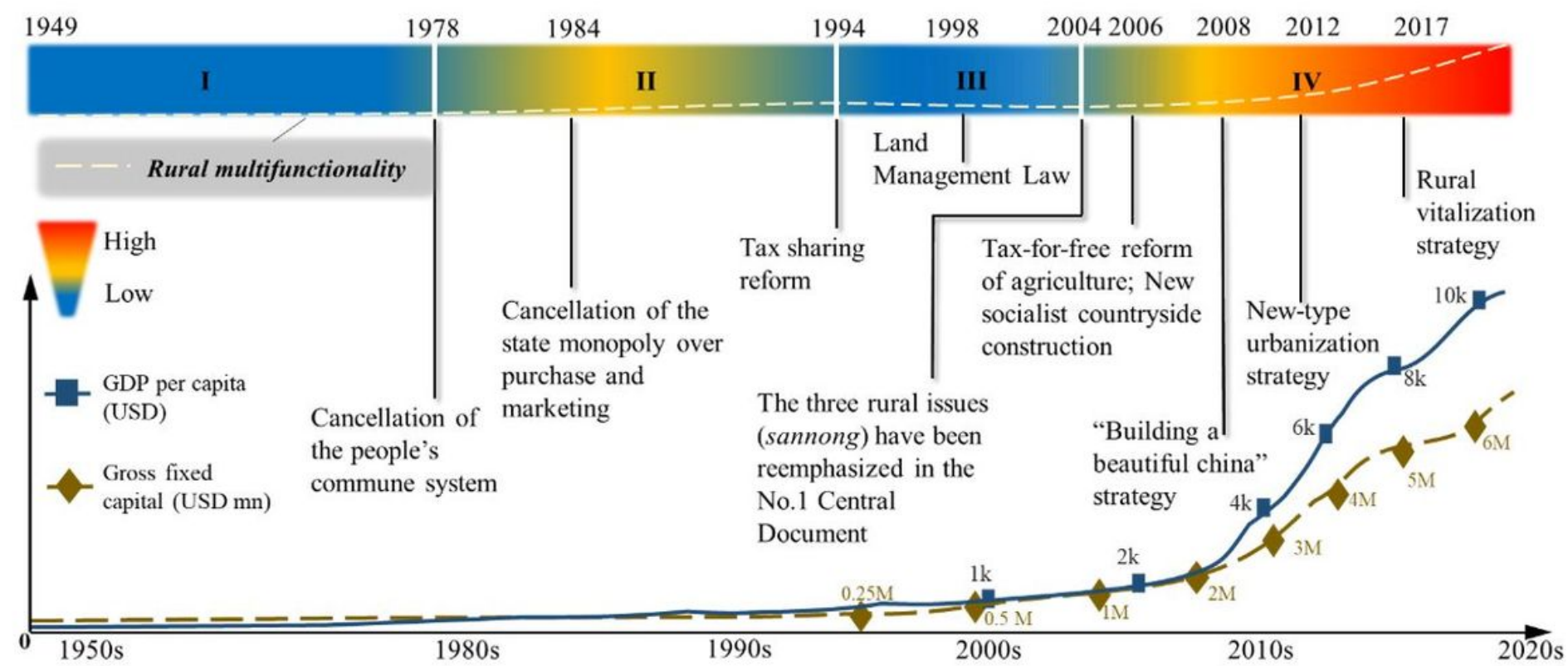

Figure 1

Trajectory of rural multifunctionality evolves in China since 1950s from the perspective of policy transformation (Source: the authors) 


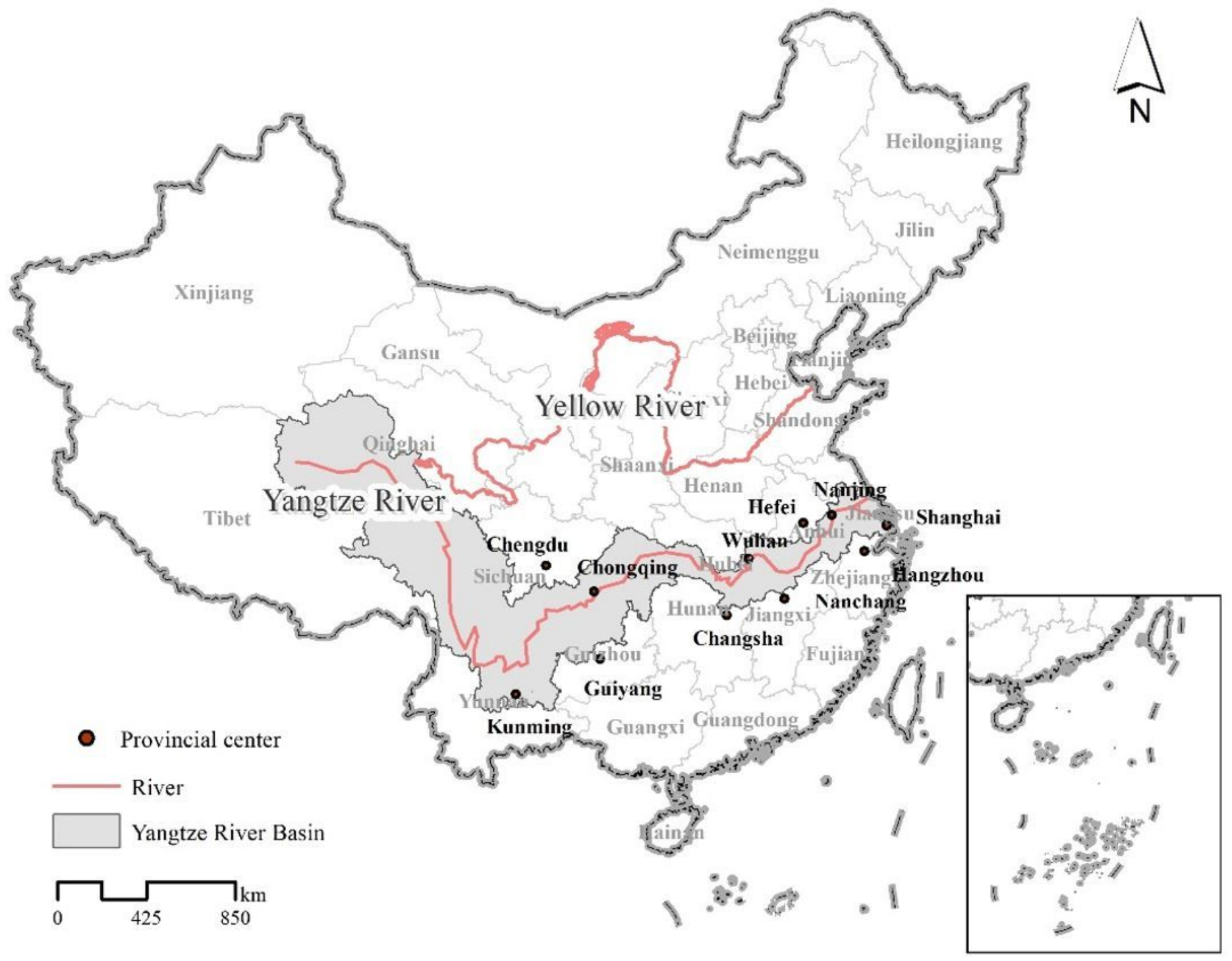

Figure 2

Profile of the study area. Note: The designations employed and the presentation of the material on this map do not imply the expression of any opinion whatsoever on the part of Research Square concerning the legal status of any country, territory, city or area or of its authorities, or concerning the delimitation of its frontiers or boundaries. This map has been provided by the authors. 

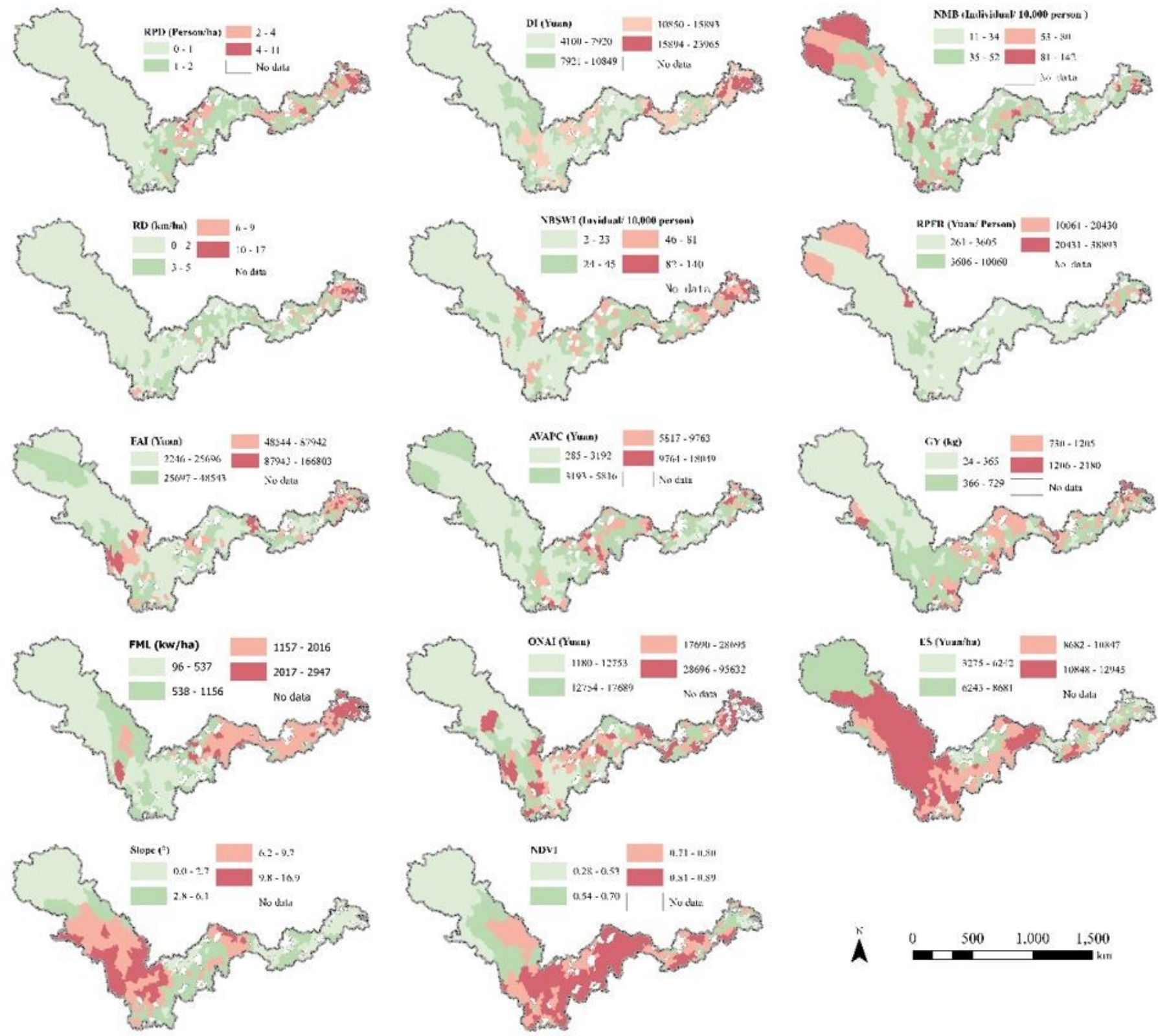

Figure 3

The spatial distribution of the selected variables. Note: The designations employed and the presentation of the material on this map do not imply the expression of any opinion whatsoever on the part of Research Square concerning the legal status of any country, territory, city or area or of its authorities, or concerning the delimitation of its frontiers or boundaries. This map has been provided by the authors. 


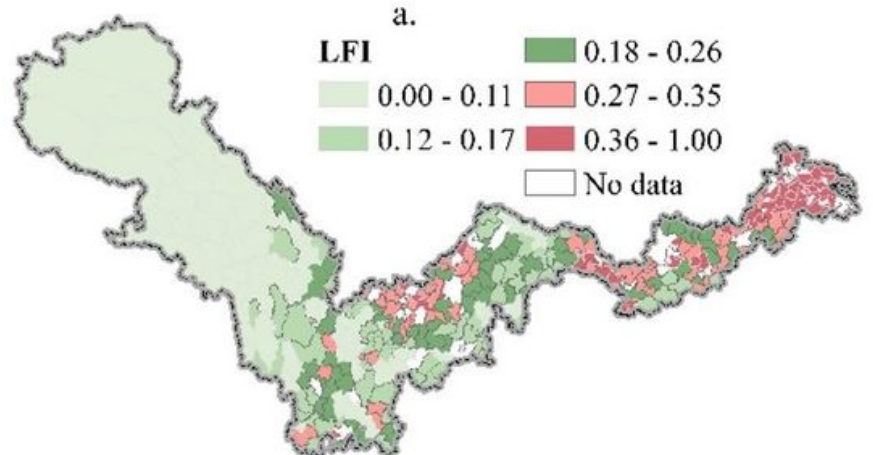

c.

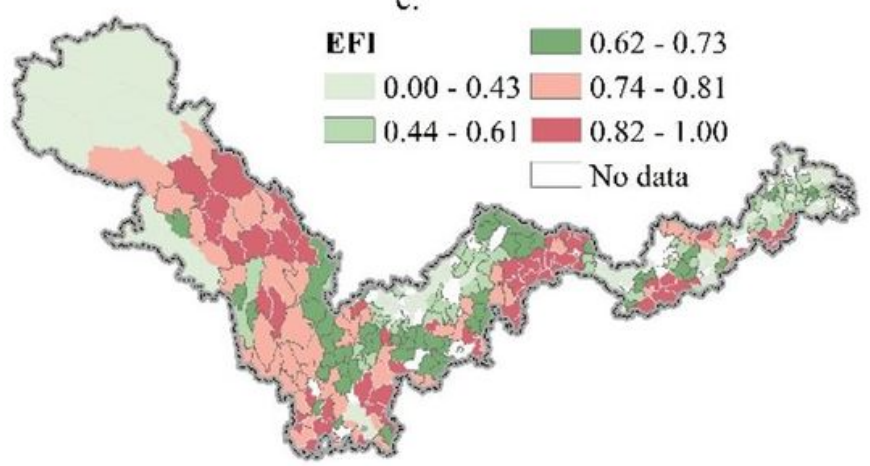

b.

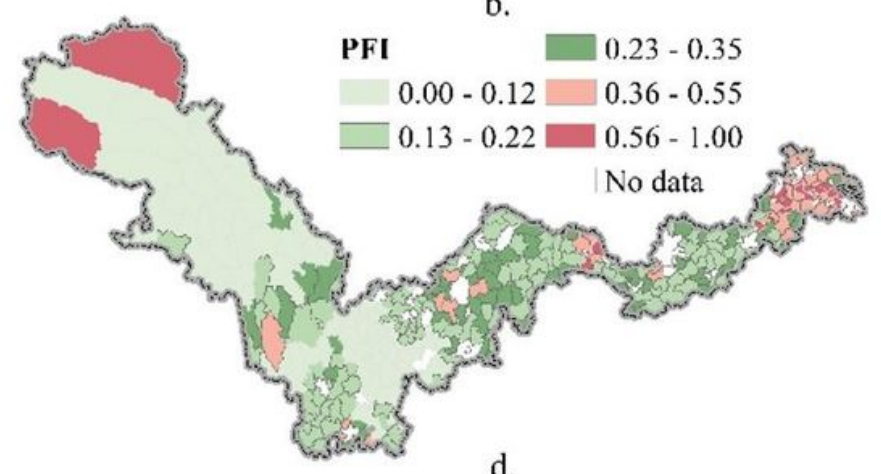

d.

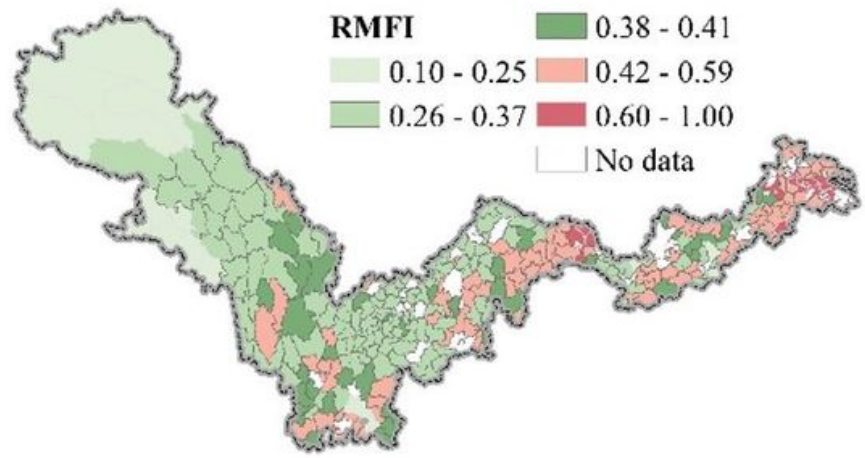

Figure 4

The spatial distribution of different indexes (The quantile method was used to classify the index). Note: The designations employed and the presentation of the material on this map do not imply the expression of any opinion whatsoever on the part of Research Square concerning the legal status of any country, territory, city or area or of its authorities, or concerning the delimitation of its frontiers or boundaries. This map has been provided by the authors.
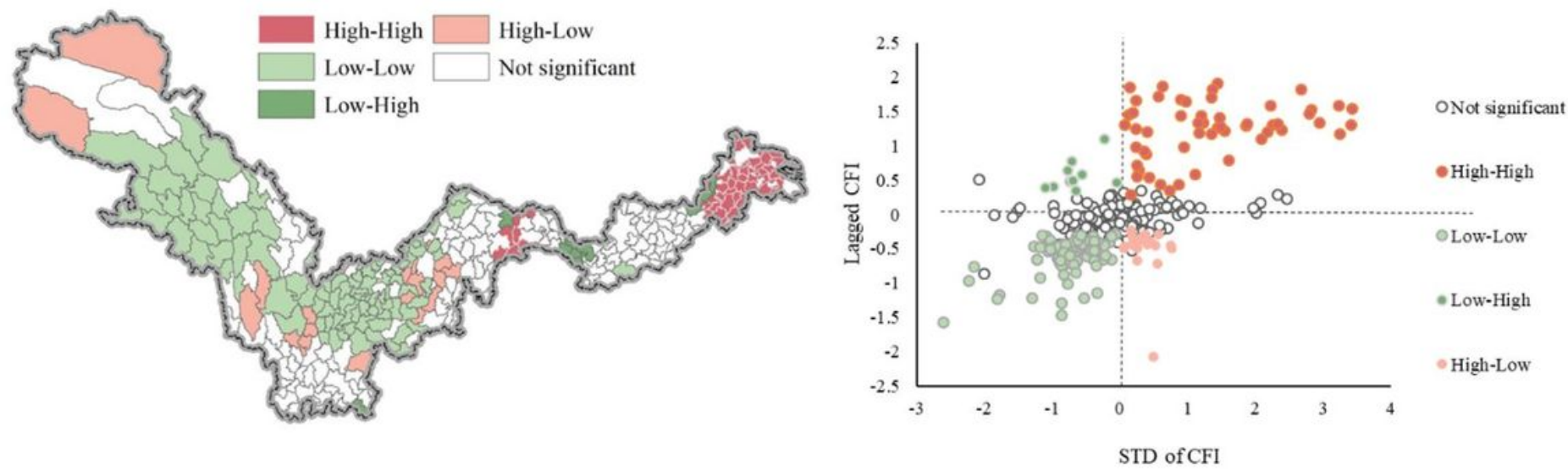

\section{Figure 5}

LISA cluster map of rural comprehensive multifunctionality index. Note: The designations employed and the presentation of the material on this map do not imply the expression of any opinion whatsoever on the part of Research Square concerning the legal status of any country, territory, city or area or of its authorities, or concerning the delimitation of its frontiers or boundaries. This map has been provided by the authors. 


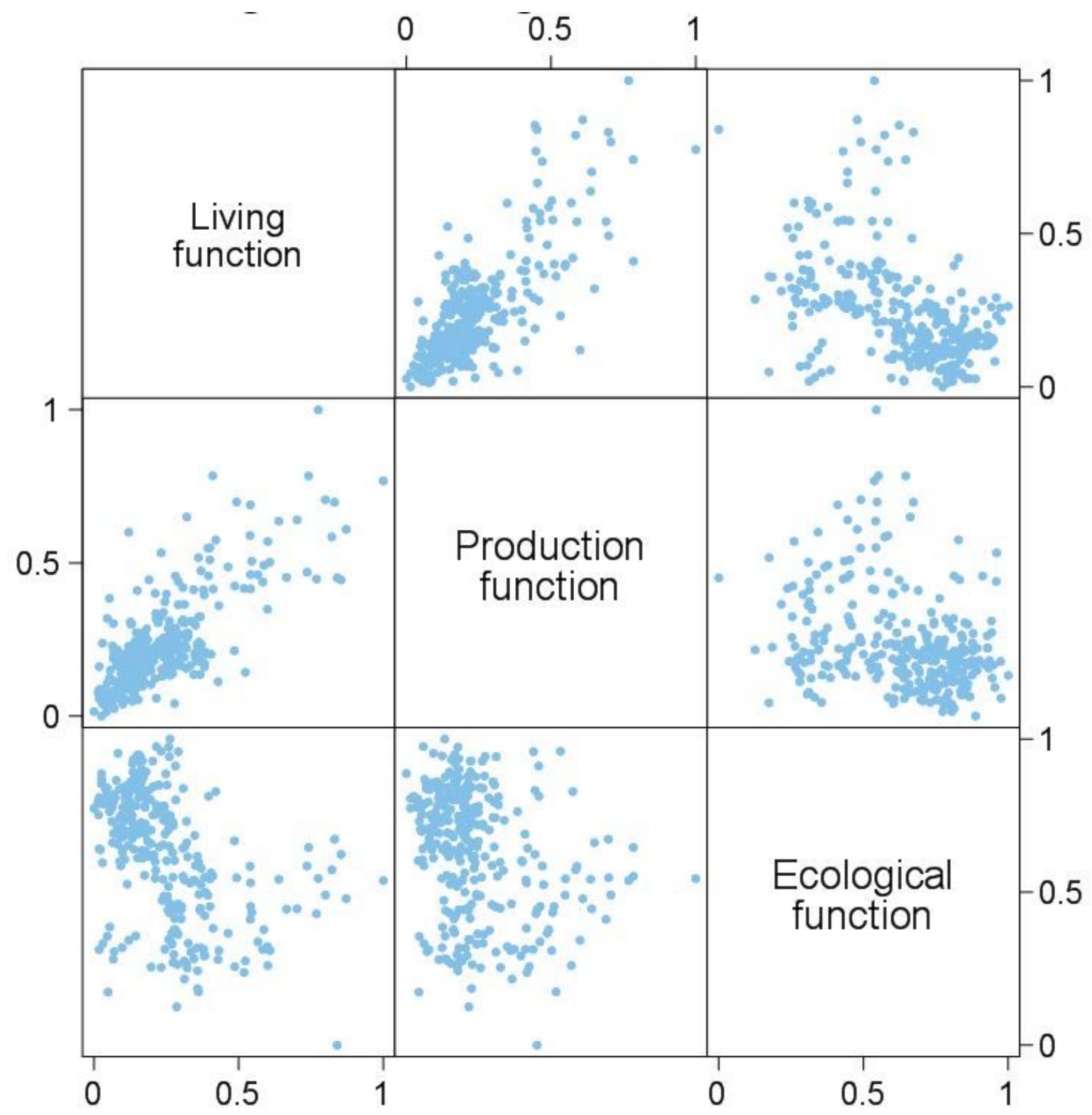

Figure 6

Graph matrix of the indexes of three dimensions. 

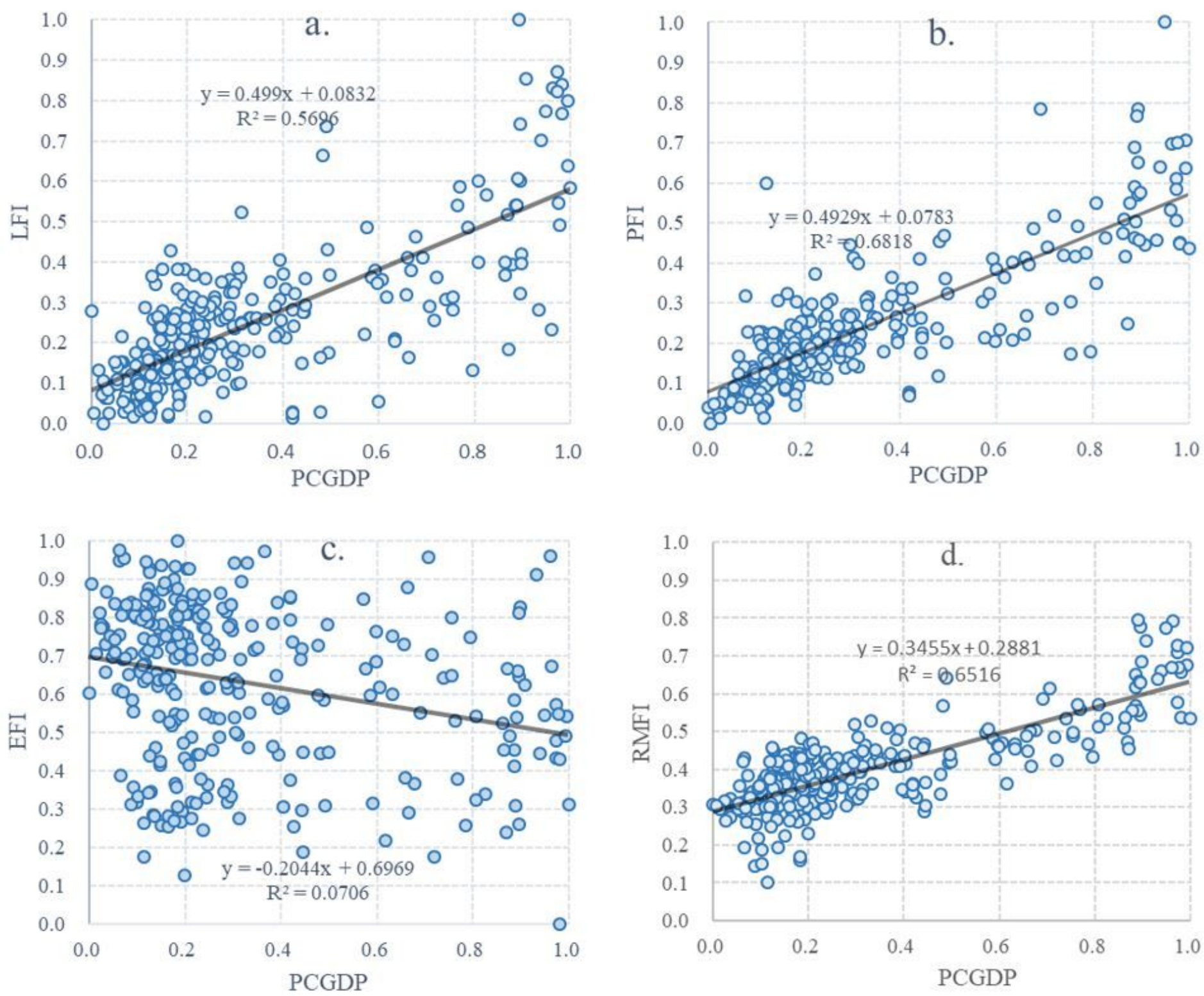

Figure 7

Scatter plots of PCGDP and different function indexes 
LFI

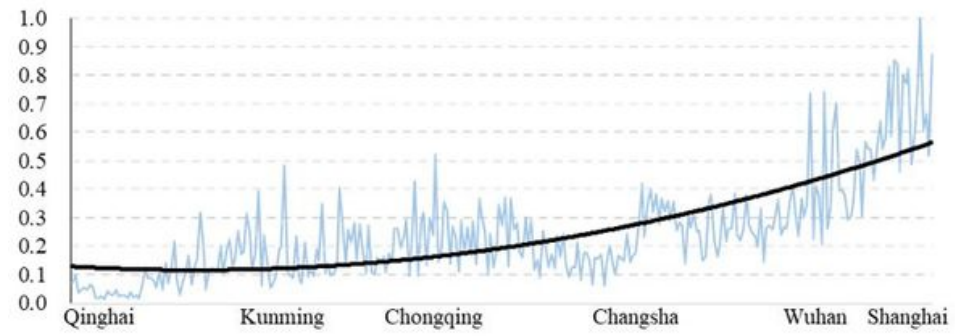

EFI

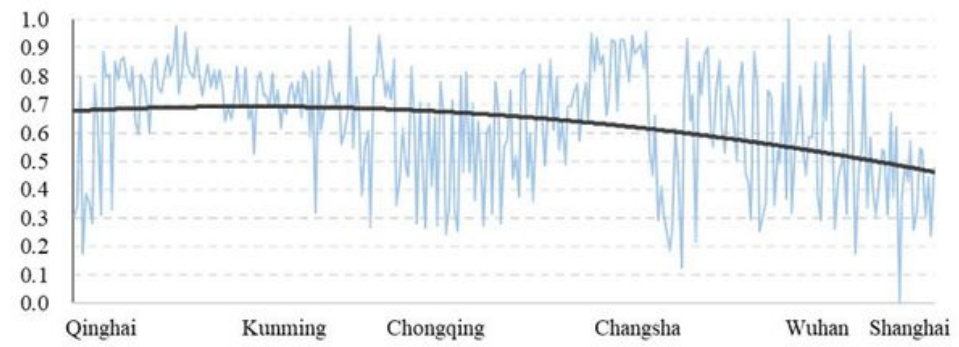

PFI

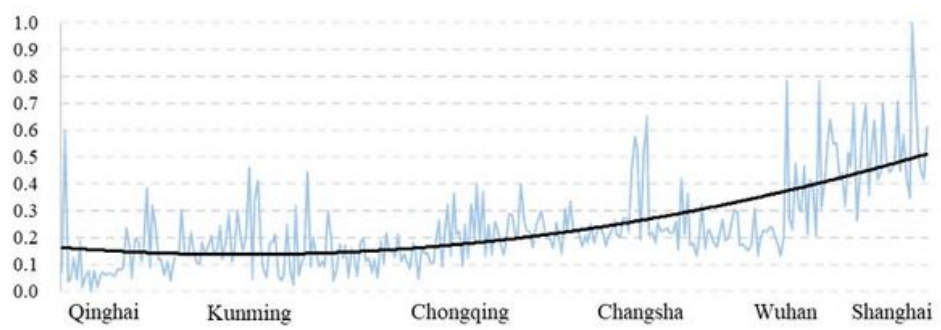

RMFI

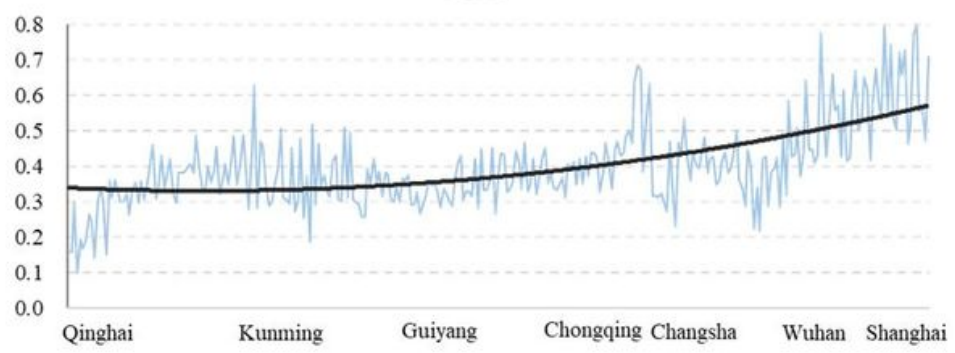

\section{Figure 8}

The spatial trend of different function indexes

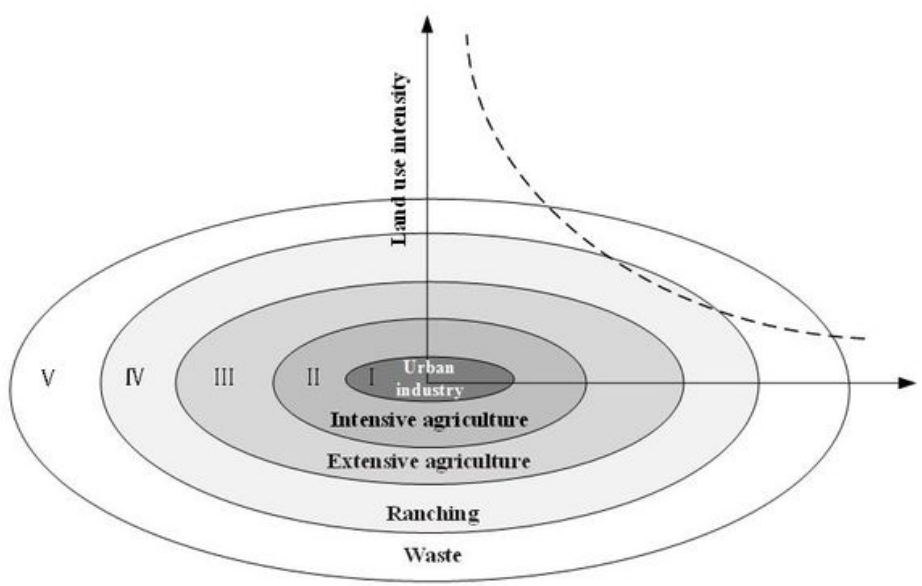

a.

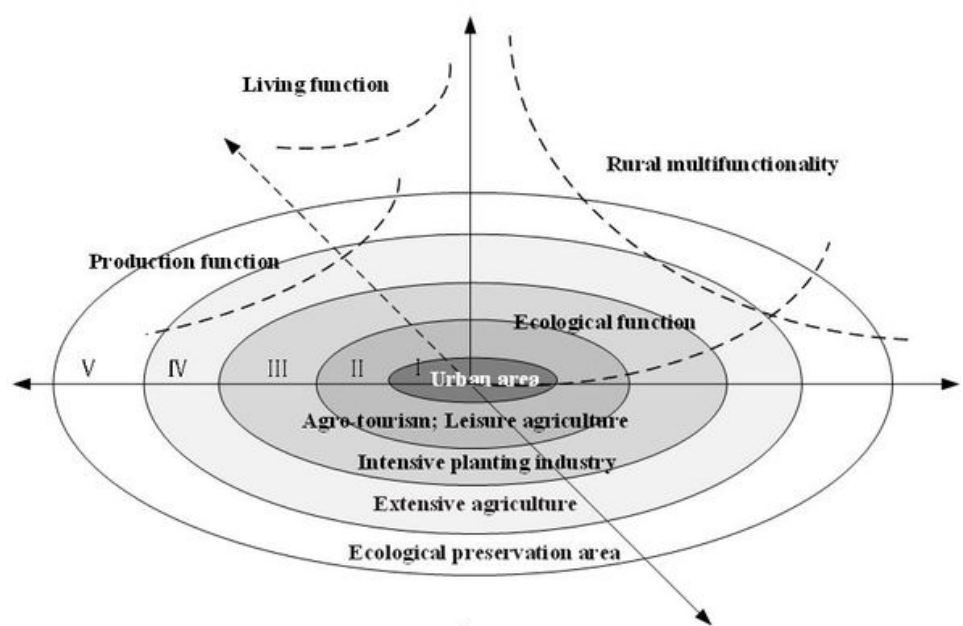

b.

Figure 9

Land use system observed by von Thünen (a.) and the spatial evolution of rural multifunctionality from urban areas to rural remoteness (b.) 